\title{
Extensometer, Water-Level, and Lithologic Data from Bacon and Bethel Islands in Sacramento-San Joaquin Delta, California, September 1987 to August 1993
}

By Barry D. Kerr and David A. Leighton

U.S. GEOLOGICAL SURVEY

Open-File Report 98-631

Prepared in cooperation with the

CALIFORNIA DEPARTMENT OF WATER RESOURCES

$\frac{\dddot{T}}{\pi}$ 


\section{U.S. DEPARTMENT OF THE INTERIOR \\ BRUCE BABBITT, Secretary}

U.S. GEOLOGICAL SURVEY

Charles G. Groat, Director

The use of firm, trade, and brand names in this report is for identification purposes only and does not constitute endorsement by the U.S. Geological Survey

For additional information write to:

District Chief

U.S. Geological Survey

Placer Hall, Suite 2012

$6000 \mathrm{~J}$ Street

Sacramento, CA 95819-6129
Copies of this report can be purchased from:

U.S. Geological Survey

Information Services

Box 25286

Federal Center

Denver, CO 80225 


\section{CONTENTS}

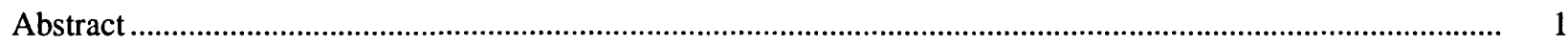

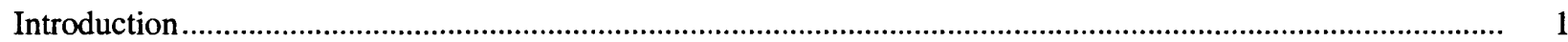

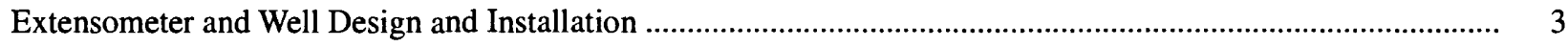

Data Measurement and Collection Methods ..................................................................................................... 7

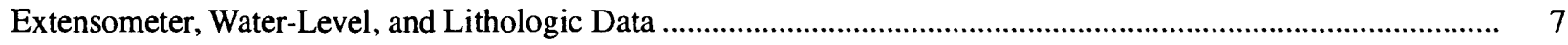

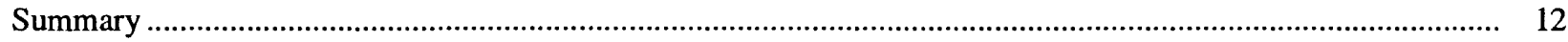

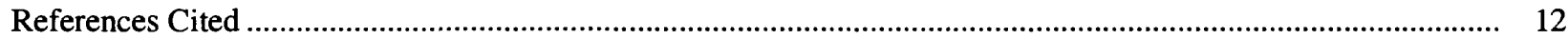

\section{ILLUSTRATIONS}

1. Map showing location of extensometer sites in the Sacramento-San Joaquin Delta, California ................ 2

2. Diagram of typical vertical extensometer ............................................................................................... 4

3-4. Schematics showing:

3. Bacon Island extensometer and piezometer construction ............................................................... 5

4. Bethel Island extensometer and piezometer construction ............................................................... 6

5-6. Graphs showing:

5. Extensometer record of compaction and depth to water from September 1987 to August 1993

for the Bacon Island site .................................................................................................................. 8

6. Extensometer record of compaction and depth to water from August 1988 to August 1993

for the Bethel Island site ............................................................................................................ 8

\section{TABLE}

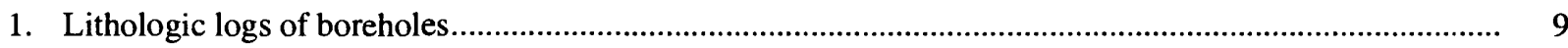

\section{CONVERSION FACTORS AND VERTICAL DATUM}

\begin{tabular}{rcl}
\hline Multiply & By & To obtain \\
\hline acre & 0.4047 & square hectometer \\
cubic yard & .7646 & cubic meter \\
foot (ft) & .3048 & meter \\
foot per year (ft/yr) & .3048 & meter per year \\
inch (in.) & 25.40 & millimeter \\
mile (mi) & 1.609 & kilometer \\
\hline
\end{tabular}

Sea level: In this report, "sea level" refers to the National Geodetic Vertical Datum of 1929 (NGVD of 1929)-a geodetic datum derived from a general adjustment of the first-order level nets of both the United States and Canada, formerly called mean sea level of 1929 . 


\section{WELL-NUMBERING SYSTEM}

The well-numbering system used by the U.S. Geological Survey (USGS) and the State of California desigrates the location of wells according to the rectangular system for the subdivision of public lands (Bader, 1969). Well identification consists of a township number, north or south; the range number, east or west; and the section number. Each section is further divided into sixteen 40 -acre tracts lettered consecutively (except I and $\mathrm{O}$ ), beginning with $\mathrm{A}$ in the northeast corner of the section and progressing in a sinusoidal manner to $\mathrm{R}$ in the southeast corner. Within ear $h$ 40-acre tract, wells are sequentially numbered in the order they are inventoried. The final letter in a well identification number refers to the base line and meridian. Wells in this study area are referenced to the Mount Diablo base line and meridian (M). The diagram below illustrates how the number 2N/4E-31R2 is derived.

The station identification number used by the USGS for wells is principally for correlation and retrieval of computerized data and is not considered a State location number. The Bacon Island extensometer number is 375811121341201 (latitude $37^{\circ} 58^{\prime} 11^{\prime \prime}$, longitude $121^{\circ} 34^{\prime} 12^{\prime \prime}$, sequence 01 ), and the water-level well number is 375811121341202. The Bethel Island extensometer number is 380208121372901 , and the water-level well numb:r is 380207121372902 .

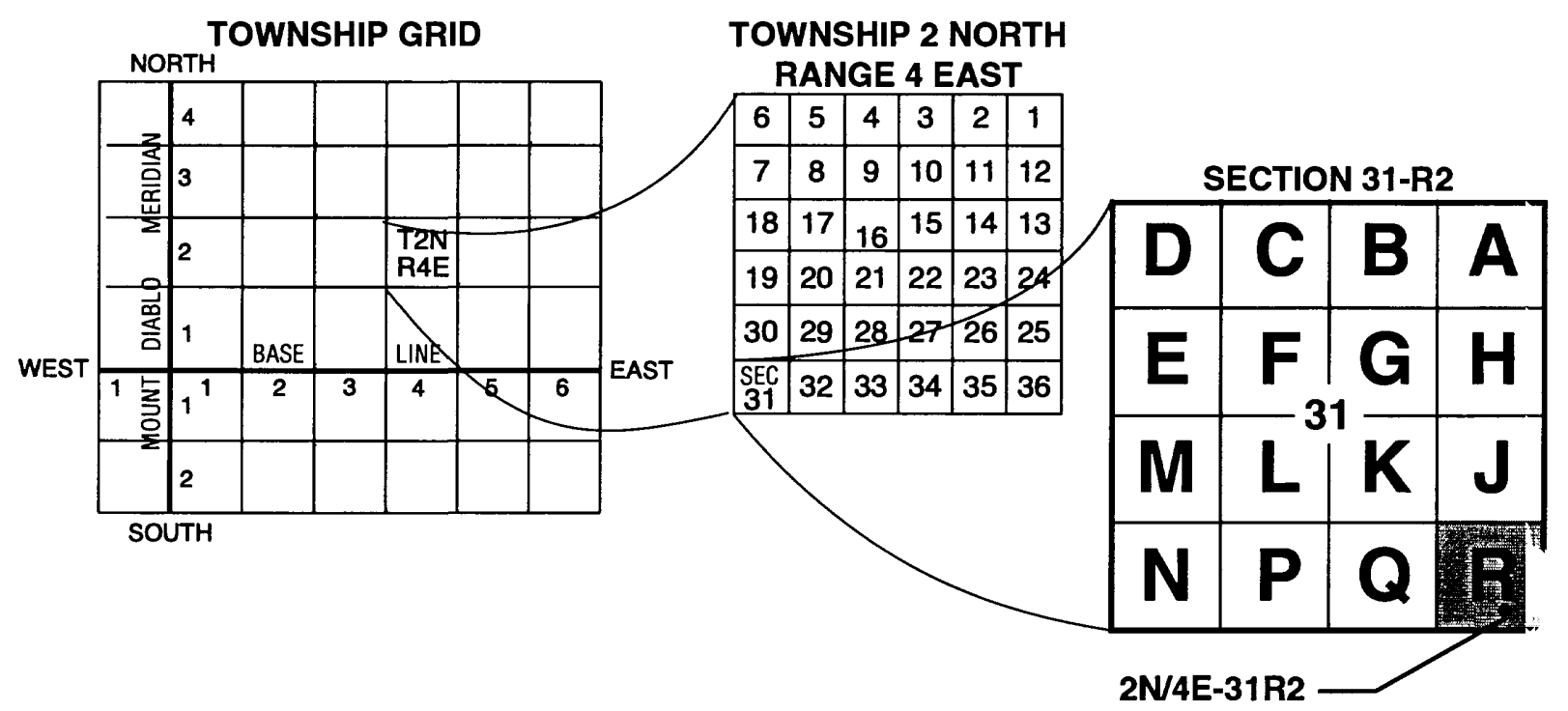




\title{
Extensometer, Water-Level, and Lithologic Data from Bacon and Bethel Islands in Sacramento-San Joaquin Delta, California, September 1987 to August 1993
}

\author{
By Barry D. Kerr and David A. Leighton
}

\begin{abstract}
Compaction, water-level, and lithologic data were collected at extensometer sites on Bac on and Bethel Islands, anchored at 436 and 536 feet below land surface, respectively. The data reported here are part of a study of the processes causing subsidence in the Sacramento-San Joaquin Delta. The depths were selected to ensure that they were well below the peat layer and the primary aquifer, which minimized the effects of peat loss and shallow ground-water withdrawal. Compaction and depth to ground water were measured monthly at Bacon Island from September 1987 through August 1993 and at Bethel Island from August 1988 through August 1993. After automatic digital data loggers were installed at Bacon Island in December 1988 and at Bethel Island in September 1989, hourly readings also were made. Calculated rates of compaction were 0.0015 and 0.0016 feet per year at Bacon and Bethel Islands, respectively. Cumulative compaction at the Bacon Island site from September 1987 to August 1993 was about 0.009 feet. Cumulative compaction at the Bethel Island site from August 1988 to August 1993 was about 0.008 feet.
\end{abstract}

\section{INTRODUCTION}

The Sacramento-San Joaquin Delta is located at the confluence of the Sacramento and San Joaquin Rivers, at the eastern end of the San Francisco-Suisun Bay, California (fig. 1). Some of the islands in the central delta are now more than $15 \mathrm{ft}$ below sea level as a result of land subsidence. Prokopovitch (1985) reported subsidence rates in the delta between 0.092 to $0.384 \mathrm{ft} / \mathrm{yr}$. Continued regional subsidence could sufficiently alter the gradients of channels and aqueducts so that transport of fresh water through the delta is adversely affected. Subsidence also can damage storm drains, sanitary sewers, roads, bridges, and railroads and cause well casings to fail due to compressive forces (Bertoldi, 1992).

Subsidence in the delta is caused primarily by oxidation of drained peat soils (Rojstaczer and Deverel, 1993). However, permanent compaction due to ground-water withdrawal also is a concern in the delta. This report presents compaction, water-level, and lithologic data collected at two extensometers. These data will help determine the effects of ground-water withdrawal on subsidence and serve as a reference to which other studies of subsidence in the organic peat layer can be compared.

These data are a result of ongoing studies of processes affecting subsidence in the delta. The studios are being done in cooperation with the California Department of Water Resources. 


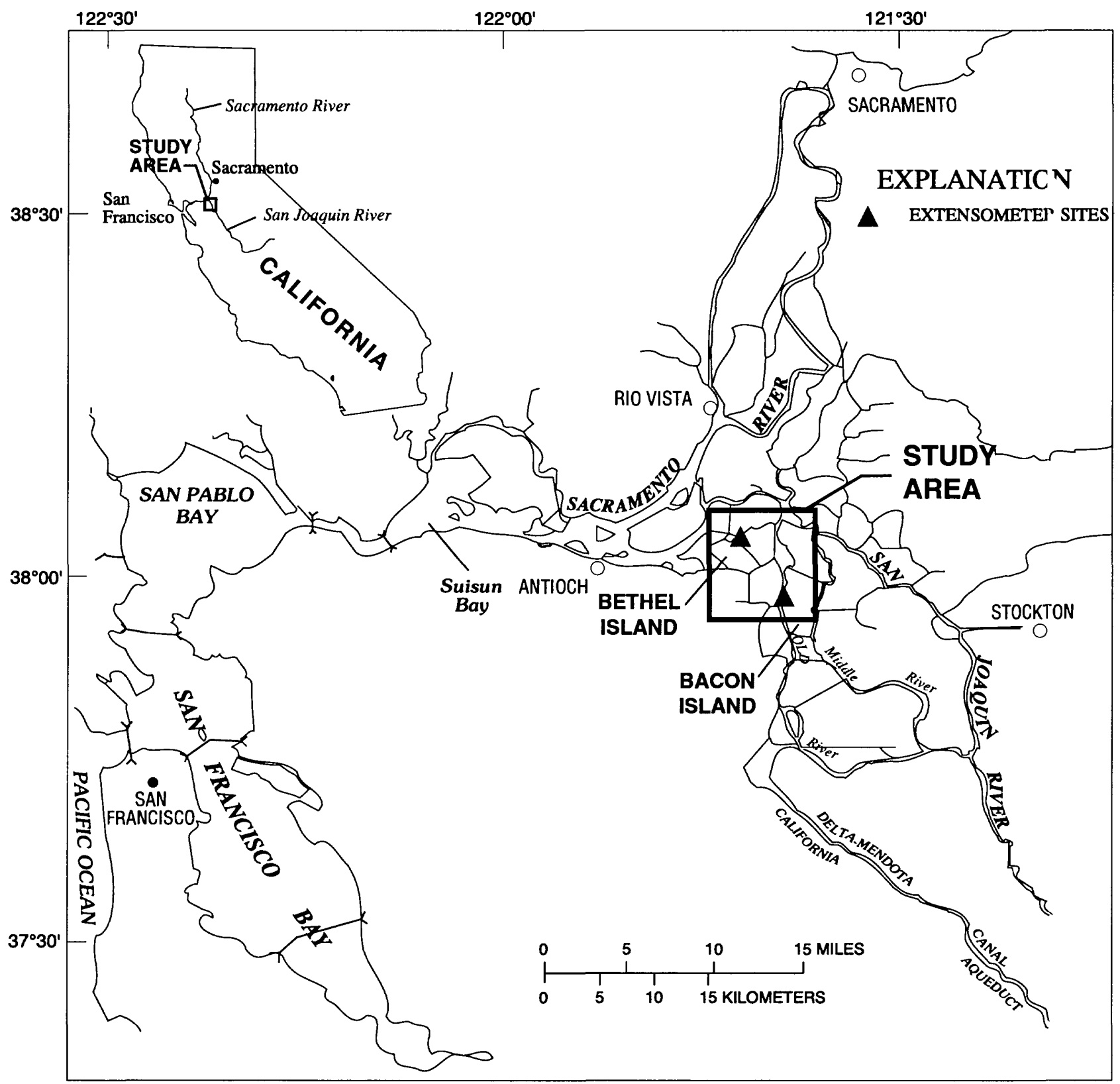

Figure 1. Location of extensometer sites in the Sacramento-San Joaquin Delta, California. 


\section{EXTENSOMETER AND WELL DESIGN AND INSTALLATION}

Extensometers, which measure compaction, were installed on Bacon Island in November 1986 and on Bethel Island in February 1988, anchored at 436 and $536 \mathrm{ft}$ below land surface, respectively. The deptl ${ }^{\circ}$ were selected to ensure that the anchors were well below the peat layer and the primary aquifer in order to minimize the effects of peat loss and shallow ground-water withdrawals on measurements. The construction design is shown in figure 2, and was modified from Hanson (1989) and Riley (1986). The steel instrument table is attached to steel pipes that are anchored in concrete at a depth of about $40 \mathrm{ft}$ below land surface, well below the peat layer. Both extensometers are 2-in. steel pipes that rest on concrete plugs and are centered inside protective 6-in. steel casing. Counterweights are suspended from the fulcrum arm (fig. 2) to relieve most of the weight of the 2-in. pipe. Ground-water monitoring wells were installed on Bacon and Betrel Islands at the same time as the extensometers.

At the Bacon Island extensometer site, a 6-in. pilot hole was drilled to a depth of $445 \mathrm{ft}$ below land surface, and the drill cuttings were used to construct the lithologic log in table 1 . The upper $36 \mathrm{ft}$ of the filot hole was reamed to 22 in. to accommodate a 14-in. steel conductor casing, which was set in concrete (fig. 3). The conductor casing serves as a hanger, from which the protective 6 -in. casing is suspended. The pilot l ole from $36 \mathrm{ft}$ to the bottom ( $445 \mathrm{ft}$ ) was reamed to 12-1/4-in. diameter to accept the 6-in. casing. A 10-ft louvered screen (0.040-in. slots), which serves as a piezometer at the site, is located between 152 and $1 € 2 \mathrm{ft}$ of the 6-in. casing. A concrete basket was attached to the casing $5 \mathrm{ft}$ below the screen. An 18-ft slip joint was installed between 362 and $380 \mathrm{ft}$. The bottom $18 \mathrm{ft}$ of the borehole was uncased. The 2-in., schedule 80 , steel extensometer pipe was centered inside the 6-in. casing and rests on a 9-ft-thick concrete plug, formed by pumping concrete down the 2 -in. pipe.

The annulus was allowed to self-fill and seal because: (1) getting the bentonite clay pellets below the runny sand layers would be difficult, (2) the expansive clay layers above and below the screened interval would naturally close in around the 6-in. casing and isolate it, (3) the coarse sand of the formation at tl ? screened interval would serve as a natural gravel pack, and (4) the concrete basket prevented sand from the borehole walls from falling farther down (fig. 3).

At the Bethel Island extensometer site, a 9-7/8-in. borehole was drilled to $39 \mathrm{ft}$ below land surfaca, then it was reamed to 15-1/2 in. to accept $39 \mathrm{ft}$ of 12-in. steel conductor casing (fig. 4). The conductor casing was cemented in place to act as a support for the 6-in. casing. The 9-7/8-in. borehole was continued to 545 $\mathrm{ft}$, and $535 \mathrm{ft}$ of 6-in. steel casing was suspended from the conductor casing. An 18-ft slip joint was installed between 477 and $495 \mathrm{ft}$. The 2-in., schedule 80, steel extensometer pipe was lowered inside the 6-in. casing to $539 \mathrm{ft}$, and concrete was pumped down the 2 -in. pipe to form the plug at the bottom of the borehole. The entire annulus at this site was allowed to self-fill and seal because no water-level monitoring well was developed in this borehole.

The water-level monitoring well, called a piezometer, on Bacon Island—as previously mentioned-- is the 6-in. steel casing with a 10-ft screened interval. Water-level monitoring wells on Bethel Island (fig. 4) were constructed in a separate borehole about $10 \mathrm{ft}$ south of the extensometer. A 9-7/8-in. borehole was drilled to $79 \mathrm{ft}$ below land surface, then reamed to 15-1/2 in. in diameter. Seventy-nine $\mathrm{ft}$ of 12 -in. steel casing was cemented in place. The 9-7/8-in. borehole was continued to a depth of $455 \mathrm{ft}$. Two 2-in. ste $: 1$ casings were installed in this hole. The deeper well has a 5-ft screened interval (0.010-in. slots) from 441 to $446 \mathrm{ft}$ and a 4-in.-long capped blank at the bottom. Sand and gravel from the borehole wall caved in aro'nd the screen. Well development showed that the caved-in sand and gravel functioned adequately as a sandgravel pack for the water-level monitoring well. Bentonite grout was pumped into the annulus from 320 to $380 \mathrm{ft}$ to isolate the well from the upper part of the borehole. The shallower well was screened from 280 to $285 \mathrm{ft}$ (0.010-in. slots), and had a 20-ft-long capped blank at the bottom and a gravel pack from 200 to $320 \mathrm{ft}$. Bentonite grout was pumped into the annulus from a depth of $200 \mathrm{ft}$ up to the bottom of the 12 -in. steel casing. 


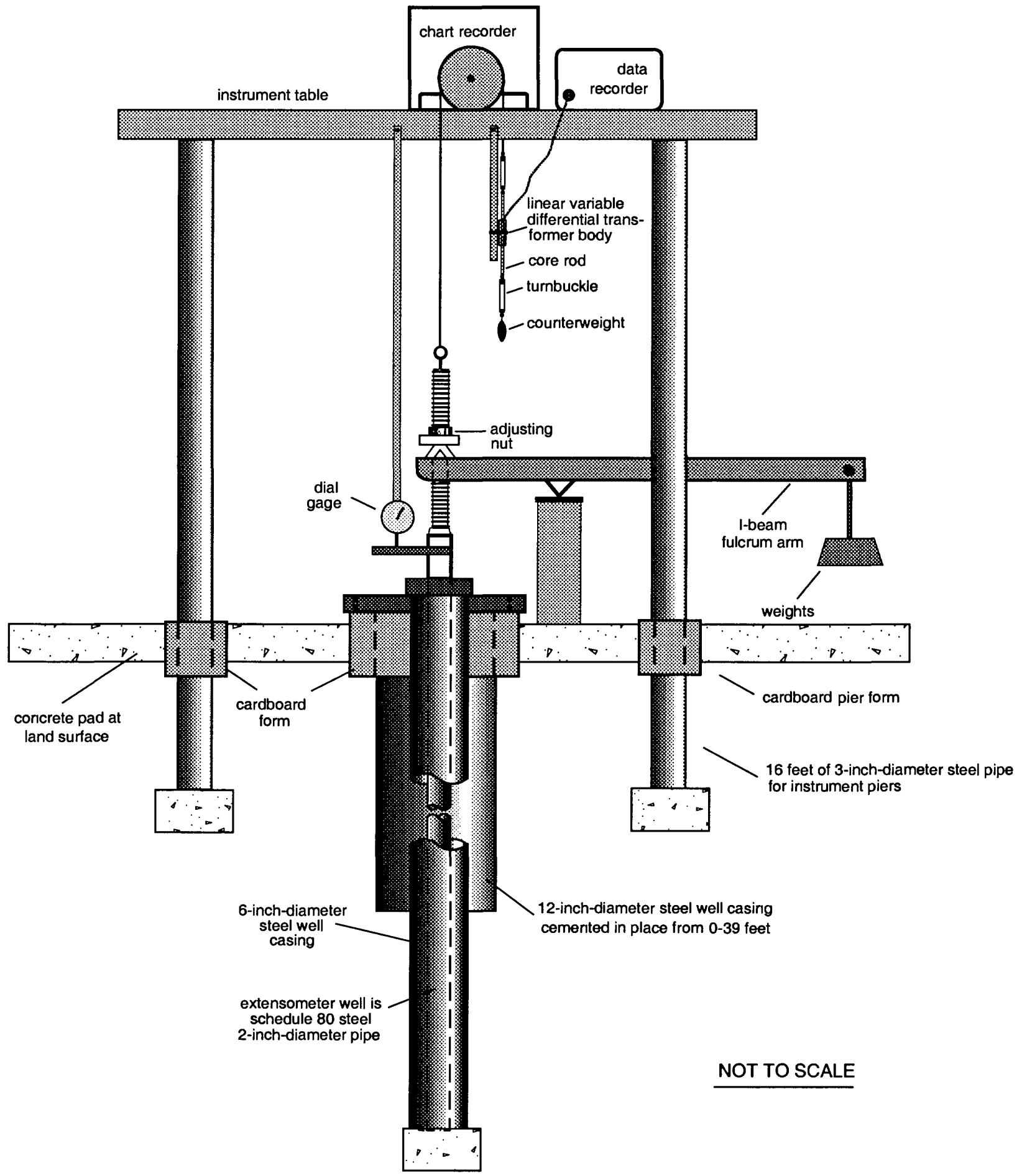

Figure 2. Diagram of typical vertical extensometer. 


\section{BACON ISLAND \\ DEEP HOLE (Borehole total depth = $\mathbf{4 4 5}$ feet) \\ (NOT TO SCALE)}

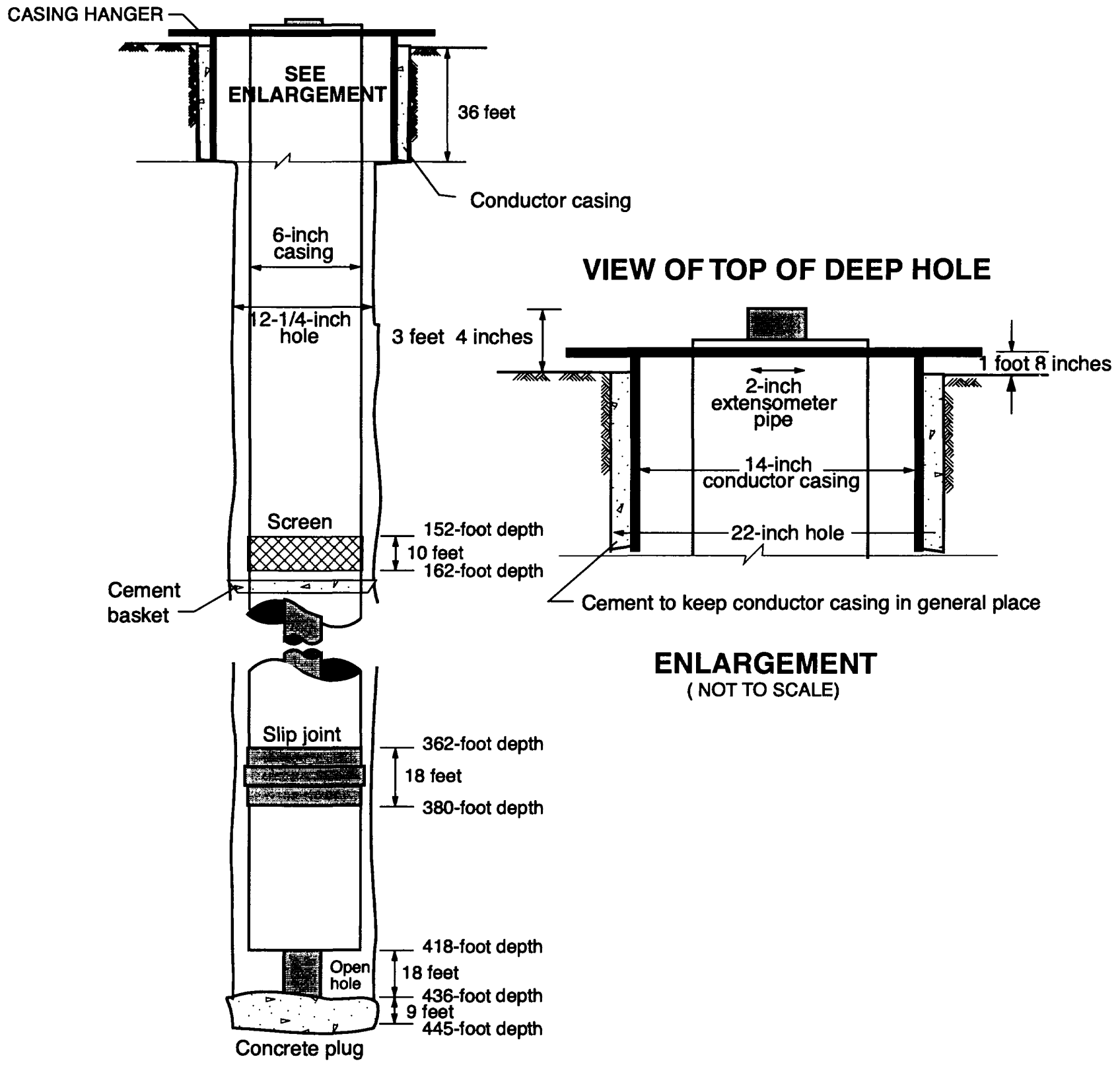

Figure 3. Bacon Island extensometer and piezometer construction. 


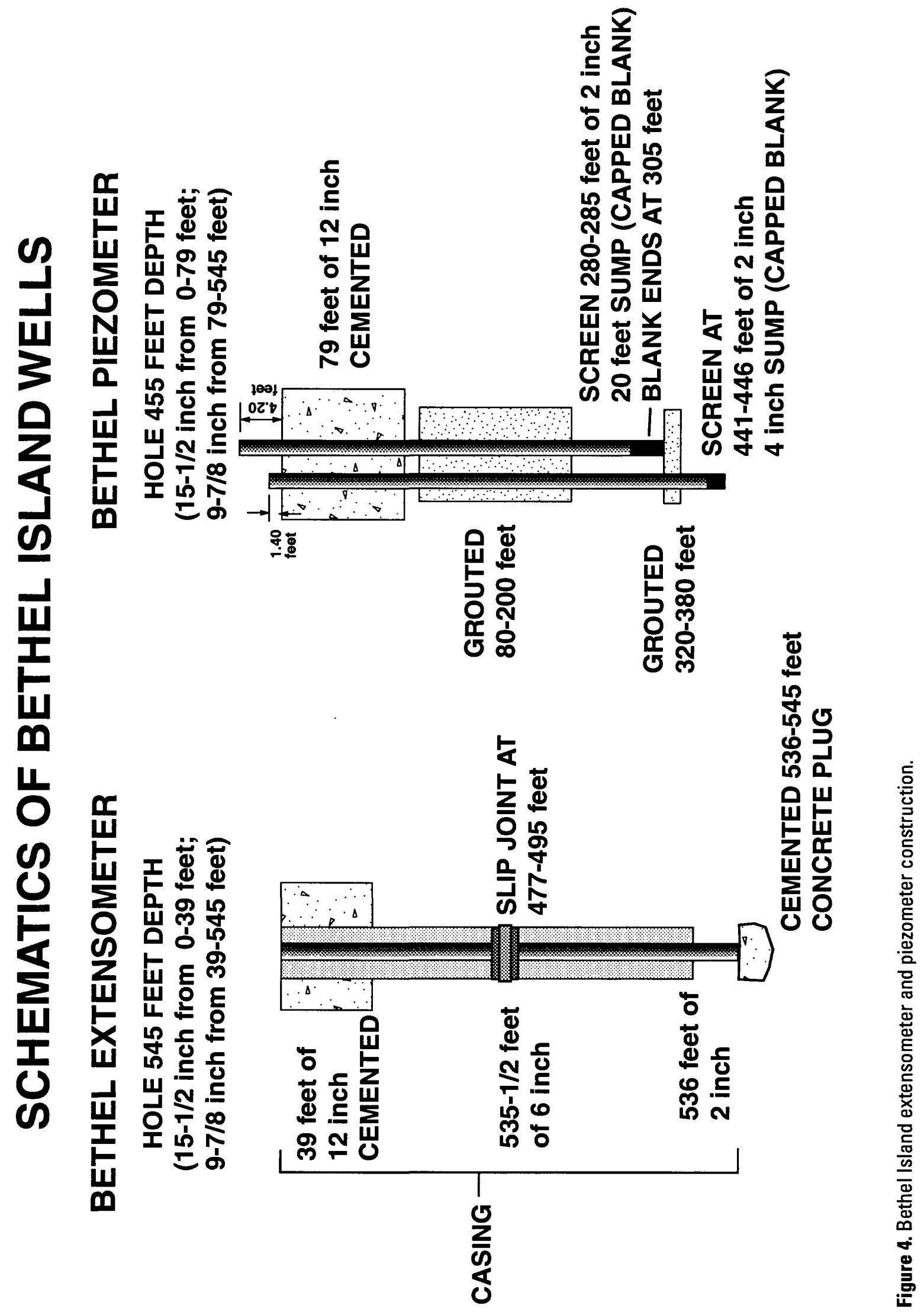




\section{DATA MEASUREMENT AND COLLECTION METHODS}

Initially, compaction was measured using Leopold and Stevens type-F analog drum recorders, an 1 water levels, as depth below land surface, were measured monthly with a steel tape in accordance witk standard U.S. Geological Survey (USGS) field procedures (U.S. Geological Survey, 1977). Then, digital data loggers, linear variable differential transformers (LVDT's), and Druck vented submersible pressure transducers were installed at Bacon Island on December 15, 1988, and at Bethel Island on September 15, 1989, after which hourly compaction and water-level measurements were recorded using digital data loggers. Compaction was measured relative to an arbitrary datum and data are not referenced to the National Geodetic Vertical Datum of 1929.

Both extensometers were fitted with micrometer dial gages that were read and recorded monthly. Regression analysis of the dial gage versus LVDT values resulted in a coefficient of determination of 96 percent for Bethel Island, even though the gage started to corrode and became temporarily inoperat ${ }^{1} \mathrm{e}$. The coefficient of determination was more than 98 percent for Bacon Island.

Data from the digital data logger were retrieved from the sites on a monthly schedule and uploadet to the USGS's Automated Data Processing System (ADAPS), located in Sacramento, California. Linear interpolation of corrections of digital data for transducer drift were computed using steel tape water-level measurements. Compaction chart recordings are not currently being processed, but are kept as backup data.

\section{EXTENSOMETER, WATER-LEVEL, AND LITHOLOGIC DATA}

Mean daily compaction and monthly manual water levels (depth to water) for Bacon and Bethel Islands are shown in figures 5 and 6. Compaction from autumn 1987 (the annual low) to spring 1993 (the annual high) was about 0.0060 and $0.0050 \mathrm{ft}$ at Bacon and Bethel Islands, respectively. Although the extensometer records show seasonal rebound, cumulative compaction was $0.009 \mathrm{ft}$ at the Bacon Island site from September 1987 to August 1993 and $0.008 \mathrm{ft}$ at the Bethel Island site from August 1988 to August 1993. For these periods, the rates of compaction (where ground-water levels were about equal) were 0.0715 and $0.0016 \mathrm{ft} / \mathrm{yr}$ at Bacon and Bethel Islands, respectively.

At Bacon and Bethel Islands, the depth from land surface to ground water was less than $6.0 \mathrm{ft}$. The well on Bethel Island experienced flowing conditions during part of the winters of 1989, 1990, 1992, and 1C:33. The annual maximum depths to ground water occurred during the dry spring months (February to April), when pumping was greatest, and the annual minimum depth to water occurred during the wet autumn months (October to December).

The lithologic logs of the boreholes are shown in table 1. Included in the table is site constructior information and land-surface datum. 


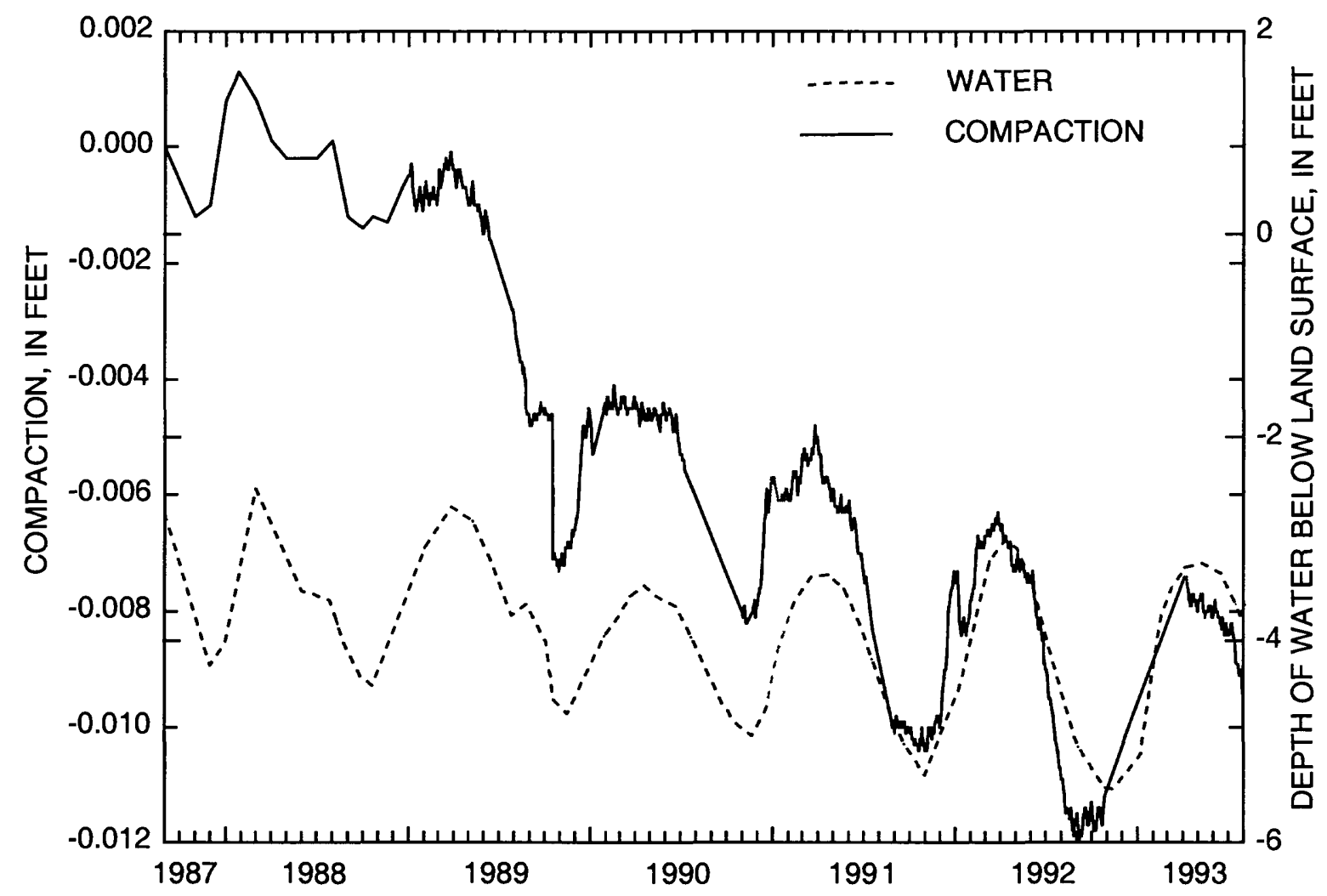

Figure 5. Extensometer record of compaction and depth to water from September 1987 to August 1993 for the Bacon Island site.

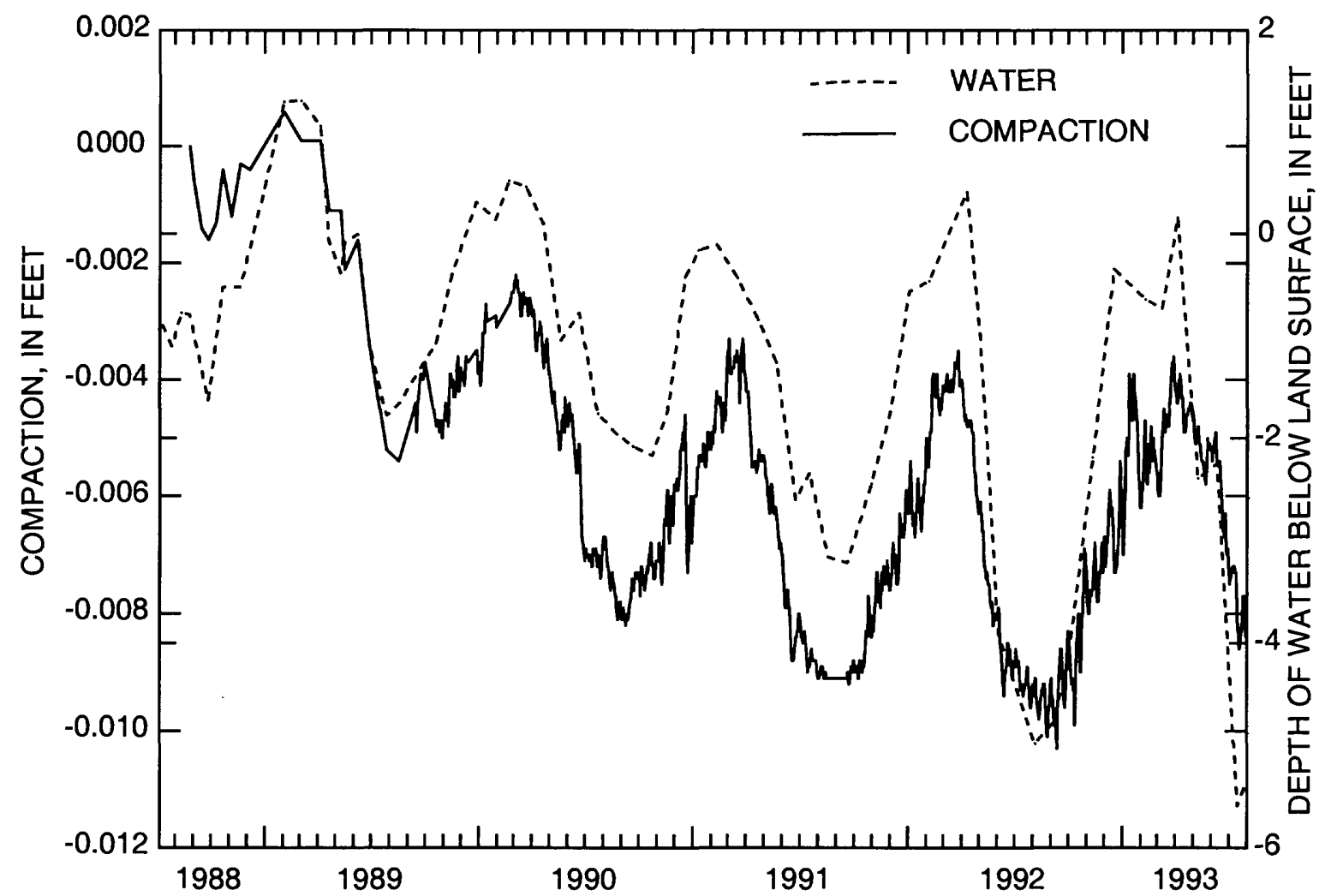

Figure 6. Extensometer record of compaction and depth to water from August 1988 to August 1993 for the Bethel Island site. 
Table 1. Lithologic logs of boreholes

[Depth in feet below sea level. NGVD, National Geodetic Vertical Datum; ft, foot; in., inch]

\begin{tabular}{|c|c|c|}
\hline \multicolumn{2}{|c|}{ Depth } & \multirow{2}{*}{ Jescription } \\
\hline From & To & \\
\hline
\end{tabular}

Bacon Island, monitoring wells 2N/4E-31R002 and 2N/4E-31R003

Because of the close proximity, the deepest borehole was used to compile the following log.

Extensometer well 2N/4E-31R002: Altitude of land surface, $-7.5 \mathrm{ft}$ (NGVD of 1929). Drilled by a U.S. Geological Survey hydraulic rotary rig, November 22, 1986. Well casing 2-in. diameter steel. Total depth $436 \mathrm{ft}$. Total borehole depth $445 \mathrm{ft}$.

Piezometer well 2N/4E-31R003: Altitude of land surface, $-7.5 \mathrm{ft}$ (NGVD of 1929). Drilled by a U.S. Geological Survey hydraulic rotary rig, November 22, 1986. Well casing 6-in. diameter steel. Total depth $418 \mathrm{ft}$. Screened interval 152 to $162 \mathrm{ft}$. Depth was measured on September 15, 1992, to be $114.23 \mathrm{ft}$ below land surface.

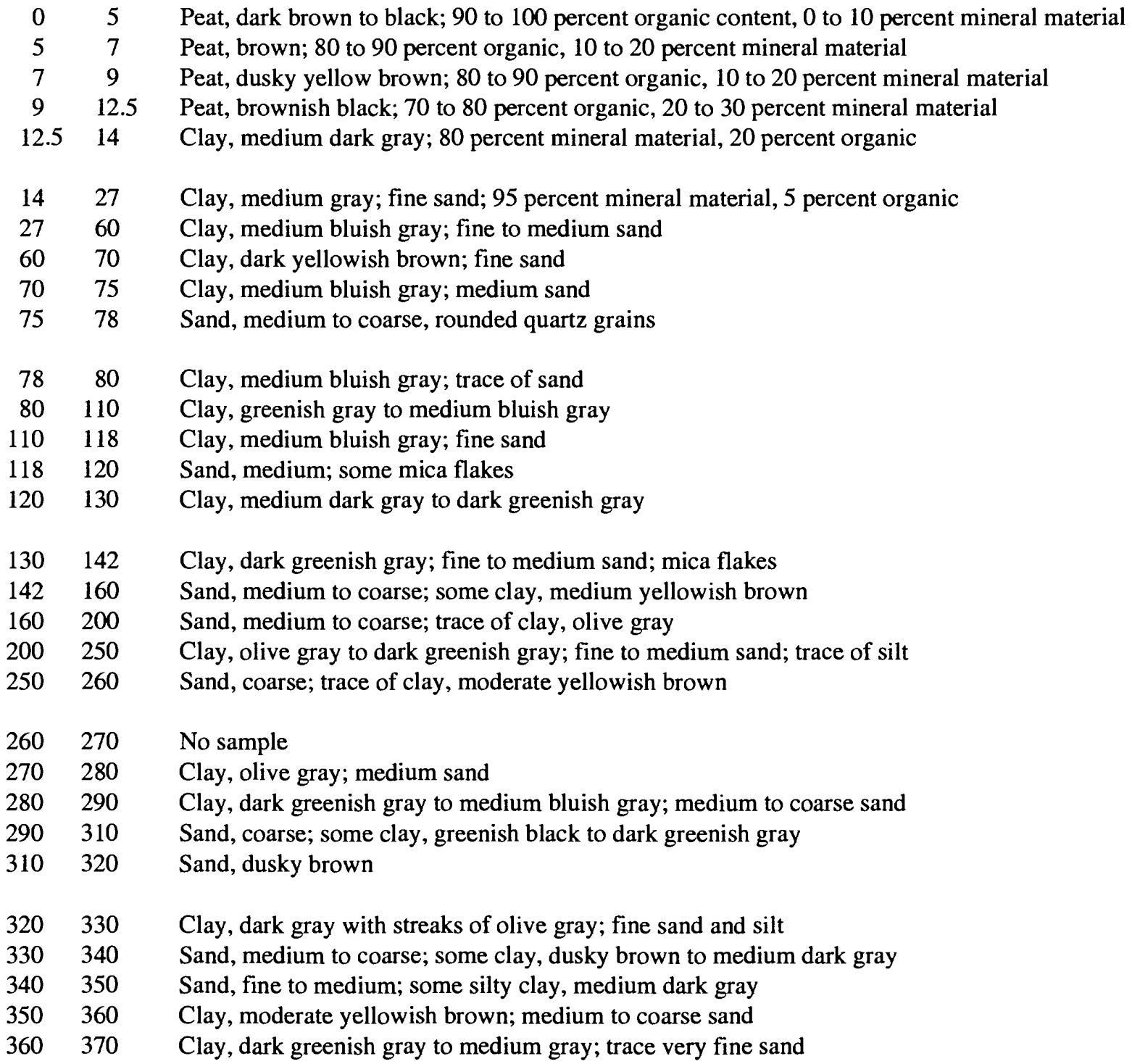


Table 1. Lithologic logs of boreholes-Continued

\begin{tabular}{ll}
\hline \multicolumn{2}{c}{ Depth } \\
From Toscription \\
\hline
\end{tabular}

Bacon Island, monitoring wells 2N/4E-31R002 and 2N/4E-31R003—Continued

$\begin{array}{lll}370 & 380 & \text { Clay, brownish gray; medium sand } \\ 380 & 400 & \text { Clay, dark yellowish orange to dark greenish gray to medium dark gray; trace cobbles } \\ 400 & 410 & \text { Sand, coarse; some clay, dusky yellowish brown } \\ 410 & 420 & \text { Clay, medium dark gray; some coarse sand } \\ 420 & 428 & \text { Clay } \\ & & \\ 428 & 433 & \text { Clay; some sand } \\ 433 & 435.5 & \text { Clay } \\ 435.5 & 438 & \text { Clay; some sand } \\ 438 & 445 & \text { Sand }\end{array}$

Bethel Island, monitoring wells 2N/3E-10H001 and 2N/3E-10H005

Because of the close proximity, the deepest test hole was used to compile the following log.

Extensometer well 2N/3E-10H001: Altitude of land surface, $-10.1 \mathrm{ft}$ (NGVD of 1929). Drilled by a U.S. Geological Survey hydraulic rotary rig, February 21,1988 . Well casing 2 -in. diameter steel. Total depth $539 \mathrm{ft}$. Total borel ole depth $545 \mathrm{ft}$.

Piezometer well 2N/3E-10H005: Altitude of land surface, $-10.1 \mathrm{ft}$ (NGVD of 1929). Drilled by a U.S. Geologiral Survey hydraulic rotary rig, February 25, 1988. Well casing 6-in. diameter steel. Screened interval 441 to $446 \mathrm{f}^{*}$.

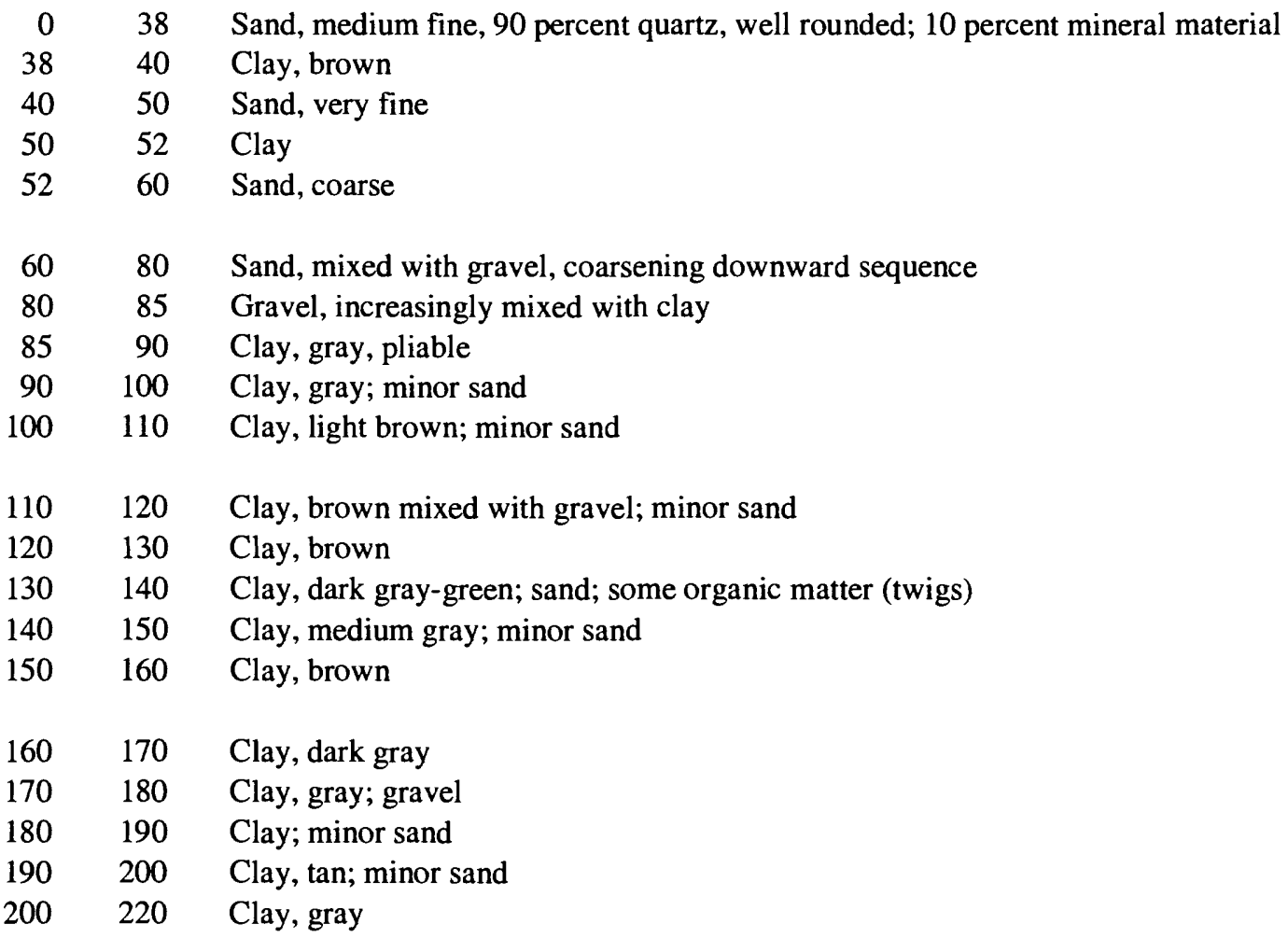


Table 1. Lithologic logs of boreholes-Continued

\begin{tabular}{|c|c|c|}
\hline \multicolumn{2}{|c|}{ Depth } & \multirow{2}{*}{ Description } \\
\hline From & To & \\
\hline
\end{tabular}

Bethel Island, monitoring wells 2N/3E-10H001 and 2N/3E-10H005-Continued

$\begin{array}{lll}220 & 250 & \text { Clay, gray; minor sand } \\ 250 & 270 & \text { Sand, fine, with small clay clods } \\ 270 & 275 & \text { Sand, fine } \\ 275 & 290 & \text { Gravel, coarse, of granodiorite origin; fine sand } \\ 290 & 300 & \text { Gravel, dark color, poorly sorted, fine sand } \\ & & \\ 300 & 335 & \text { Gravel, dark color, poorly sorted } \\ 335 & 360 & \text { Clay; coarse gravel } \\ 360 & 372 & \text { Sand, coarse black; minor clay, lots of silt } \\ 372 & 380 & \text { Clay; minor sand } \\ 380 & 397 & \text { Clay, gritty; minor sand } \\ & & \\ 397 & 400 & \text { Clay, gritty; major sand } \\ 400 & 410 & \text { Clay, gritty } \\ 410 & 430 & \text { Sand, fine; gritty clay } \\ 430 & 437.5 & \text { Clay, gray, hard, gritty } \\ 437.5 & 455 & \text { Sand, coarse, poorly sorted black with lots of silt } \\ & & \\ 455 & 495 & \text { Clay, tan, gritty } \\ 495 & 505 & \text { No sample } \\ 505 & 525 & \text { Clay, tan, gritty } \\ 525 & 530 & \text { Clay, gray, pliable } \\ 530 & 540 & \text { Clay, tan, hard } \\ 540 & 545 & \text { Clay, tan, silty, pliable }\end{array}$




\section{SUMMARY}

Subsidence in the Sacramento-San Joaquin Delta is primarily caused by oxidation of drained peat soils. This report presents compaction, water-level, and lithologic data collected at two extensometer sites. These data will be used to determine the effects of ground-water withdrawal on subsidence. Compaction was measured between instrument tables referenced to steel pipes cemented about $40 \mathrm{ft}$ below land surface (well below the peat layer) and concrete plugs at 436 and $536 \mathrm{ft}$ on Bacon and Bethel Islands, respectively. Ground-water levels were measured in wells with screened intervals of 152 to $162 \mathrm{ft}$ and 441 to $446 \mathrm{ft}$ below land surface on Bacon and Bethel Islands, respectively. The rate of compaction at Bacon Island was $0.0015 \mathrm{ft} / \mathrm{yr}$. Bethel Island showed a compaction rate of $0.0016 \mathrm{ft} / \mathrm{yr}$. Cumulative compaction at the Bacon Island site from September 1987 to August 1993 was about $0.009 \mathrm{ft}$. Cumulative compaction at the Bethel Island site from August 1988 to August 1993 was about $0.008 \mathrm{ft}$.

\section{REFERENCES CITED}

Bader, J.S., 1969, California District manual water-well and spring numbering: U.S. Geological Survey Open-File Report, 11 p.

Bertoldi, G.L., 1992, Subsidence and consolidation in alluvial aquifer systems, in Proceedings of the Eighteenth Biennial Conference on Ground Water-Changing practices in ground water management--the pros and cons of regulation: Water Resources Center, University of California Riverside, Report No. 77, p. 62-74.

Hanson, R.T., 1989, Aquifer-system compaction, Tucson Basin and Avra Valley, Arizona: U.S. Geological Survey Water-Resources Investigations Report 88-4172, 11 p.

Prokopovitch, N.P., 1985, Subsidence of peat in California and Florida: Bulletin of Association of Engineering Geologists, v. 23, p. 395-420.

Riley, F.S., 1986, Developments of borehole extensometry: International Association of Hydrological Sciences, v. 151, p. 169-186.

Rojstaczer, S.A., and Deverel, S.J., 1993, Time dependence in atmospheric carbon inputs from drainage of organic soils: Geophysical Research Letters, v. 20, no. 13, p. 1383-1386.

U.S. Geological Survey, 1977, National handbook of recommended methods for water-data acquisitic $\eta$, Chapter 2, Ground water: U.S. Geological Survey, 149 p. 